\title{
Physicochemical properties and antioxidant activities of pumpkin seed oil as affected by different origins and extraction methods
}

\author{
Irnawati Irnawati ${ }^{1}$ (D), Sugeng Riyanto ${ }^{2}$, Sudibyo Martono², Anjar Windarsih ${ }^{3}$, Abdul Rohman $^{2,4 *}$ (D) \\ ${ }^{1}$ Faculty of Pharmacy, Halu Oleo University, Kendari, Indonesia. \\ ${ }^{2}$ Department of Pharmaceutical Chemistry, Faculty of Pharmacy, Universitas Gadjah Mada, Yogyakarta, Indonesia. \\ ${ }^{3}$ Research Division for Natural Product Technology BPTBA, Indonesian Institute of Sciences LIPI, Yogyakarta, Indonesia. \\ ${ }^{4}$ Center of Excellence, Institute for Halal Industry and Systems (IHIS), Universitas Gadjah Mada, Yogyakarta, Indonesia.
}

\begin{tabular}{l}
\hline ARTICLE INFO \\
\hline Received on: 27/06/2021 \\
Accepted on: 09/09/2021 \\
Available Online: 05/03/2022 \\
\hline Key words: \\
Pumpkin seed oil, fats and \\
oils characterization, DPPH \\
assay, ultrasound-assisted \\
extraction.
\end{tabular}

\begin{abstract}
The properties of pumpkin seed oil (PSO) determined by the physical and chemical characteristics from different origins extracted using the hot pressing, Soxhlet, and ultrasound-assisted extraction methods were evaluated. The different extraction techniques of PSO were evaluated using physicochemical parameters such as yield, constants of acid, saponification, peroxide, iodine values (IVs), composition of fatty acids, and antioxidant activity. Total phenolic content was also investigated. The result showed that different extraction methods affected the physicochemical properties of PSO. PSO from Gunungkidul, Yogyakarta, extracted by hot pressing had the highest antioxidant activity against 2,2 diphenyl-1-picryhydrazyl (DPPH) (98.71\%) and 2,2'-azinobis(3-ethylbenzothiazoline-6-suslfonic acid $(\mathrm{ABTS})^{\circ+}(88.08 \%)$. Meanwhile, PSO from Pati, Central Java, extracted by Soxhlet had the highest antioxidant activity based on the $\beta$-carotene bleaching method (73.28\%). PSO from different origins extracted by different extraction methods has different total phenolic content. This study shows the potential antioxidant activities of PSO extracted using hot pressing with good physicochemical properties that would be suitable for industrial application.
\end{abstract}

\section{INTRODUCTION}

Pumpkin (Cucurbita moschata Duchesne), a member of the Cucurbitaceae family, is widely grown in tropical regions (Fig. 1a). Pumpkin flesh is cooked and consumed in many ways, such as cakes, candies, bread (Kim et al., 2012), jams, purées, juices, and alcoholic-derived beverages (Jiao et al., 2014). Pumpkin seeds can be considered as a potential source for obtaining some bioactive compounds with health benefits including tocopherol, phenolics, carotenoids, and sterols (Jiao et al., 2014; Nakić et al., 2006; Rezig et al., 2012, Rezig et al., 2018; Stevenson et al., 2007). The oil extracted from pumpkin seed, known as pumpkin seed oil (PSO), contains main fatty acid (FA) components including palmitic (C16:0), palmitoleic (C16:1), stearic (C18:0),

\footnotetext{
*Corresponding Author

Abdul Rohman, Department of Pharmaceutical Chemistry, Faculty of Pharmacy, Universitas Gadjah Mada, Yogyakarta, Indonesia. E-mail:abdulkimfar@gmail.com
}

oleic (C18:1), linoleic (C18:2), and linolenic (C18:3) acids (Perez Gutierrez, 2016). In certain countries, including Argentina, Brazil, China, India, Korea, and Mexico, PSOs have been exploited as traditional medicine in folk remedies.

In recent years, PSO has received considerable attention because of its protective effects on human health (Murkovic et al., 2004). Numerous researches have reported about the beneficial effects of PSO (Rohman and Irnawati, 2020), such as improving urinary disorders in human overactive bladder (Nishimura et al., 2014), reducing postprandial glycemia (Cândido et al., 2018), protective effect against cytotoxicity and genotoxicity (Elfiky et al., 2012), cancer cell growth inhibition (Medjakovic et al., 2016), antidiabetic activity (Bharti et al., 2013), and antioxidant activity (Jiao et al., 2014; Stevenson et al., 2007).

In industrial production, PSO is produced by hydraulic cold pressing (Salgin and Korkmaz, 2011). Numerous researches have reported about the physical and chemical characterization of PSO extracted by cold pressing (Kulaitienè et al., 2018; Rezig et al., 2012), aqueous enzymatic extraction assisted by microwave (Jiao 
et al., 2014), Soxhlet (Montesano et al., 2018), and supercritical $\mathrm{CO}_{2}$ (Koubaa et al., 2017). The temperature during the extraction process could affect the oil properties and minor constituents with some biological activities which are useful for maintaining human health conditions (Khoddami et al., 2011). Rezig et al. (2018) have compared the physicochemical properties of PSO extracted using two different methods, namely solvent extraction and cold pressing. However, the comparison of physicochemical properties of PSO as affected by three extraction methods has not been reported. The objective of this research was to compare the physical and chemical characterization, the profiles of FAs, and the antioxidant activities of PSO obtained from different origins and extraction methods.

\section{MATERIALS AND MEHTODS}

\section{Materials}

The pumpkin fruits were collected from 10 regions in Central Java and Yogyakarta, Indonesia. The seeds were separated from the flesh, cleaned, washed, and air-dried at room temperature $(3 \times 24$ hours $)$ and then stored at $-20^{\circ} \mathrm{C}$ until used for analysis and extraction.

\section{Moisture content}

The moisture content was determined based on the Indonesian Pharmacopeia (The Ministry of Health, 1979).

\section{Microwave pretreatment}

The pumpkin seed was previously subjected to pretreatment as mentioned in Irnawati et al. (2021). Inside the microwave model MR-5750 (Hitachi, Japan), $100 \mathrm{~g}$ of pumpkin seed samples was placed in an even layer in Pyrex petri dishes. The samples were subjected to microwave extraction by treating those for 240 seconds at a power of $50 \%$.

\section{Oil extraction}

During the extraction of PSO, three extraction techniques (Soxhlet, hot pressing, and ultrasound-assisted) were employed. Using the hot pressing method, pumpkin seeds previously treated with microwave were extracted using mechanical pressing (Maksindo MKS-J03) in hot conditions (Dang and Bui, 2019). The obtained oil was then separated from its sediment using a centrifuge (Thermo Scientific, USA) at 2,500 rpm for 10 minutes and stowed in a freezer at a temperature of $-20^{\circ} \mathrm{C}$ for further analysis. For Soxhlet extraction, pumpkin seed powder ( $33 \mathrm{~g})$ was continuously extracted with $500 \mathrm{ml}$ of $n$-hexane for eight cycles at a temperature of $80^{\circ} \mathrm{C}$ in a set of Soxhlet extraction apparatuses. Once the Soxhlet extraction was complete, $n$-hexane was evaporated at $50^{\circ} \mathrm{C}$ using a rotary evaporator (IKA-Werke KRV06-ML, Germany). The oil obtained was weighed to calculate the yield of oil extraction. In ultrasound-assisted extraction (UAE), PSO was extracted using ultrasonic cleaning (ELMA, T760/DH) according to the method described by Irnawati et al. (2020). Briefly, $50 \mathrm{~g}$ of pumpkin seed powder was mixed with $500 \mathrm{ml} n$-hexane and sonicated at $150 \mathrm{~W}$ for 15 minutes at a temperature lower than $40^{\circ} \mathrm{C}$. The solvent was later separated from the sediment using a centrifuge (Thermo Scientific, USA) at 2,500 rpm for 10 minutes.
After that, the samples were treated as previously reported using Soxhlet extraction.

\section{Physical and chemical characterization of PSO}

Determination of some values (acid, saponification, peroxide, and iodine) of PSO was carried out according to the methods of the AOAC (2000).

\section{Evaluation of FA profiles}

The FA profiles of PSO were analyzed according to Rezig et al. (2018) using gas chromatography (GC) with slight modifications. The nonvolatile FAs were subjected to derivatization by converting them into FA methyl esters (FAMEs). This derivatization was carried out by adding $0.4 \mathrm{~g}$ PSO with $1.5 \mathrm{ml}$ of methanolic potassium hydroxide and $2 \mathrm{ml}$ of boron trifluoridemethanol. The FAME in heptane was analyzed by GC (Agilent Technologies, 7890B) equipped with a capillary column of DBWAX $(30 \mathrm{~m} \times 250 \times 0.25 \mu \mathrm{m})$. The temperatures of the injection inlet and detector (flame ionization detector) were set at $250^{\circ} \mathrm{C}$ and $280^{\circ} \mathrm{C}$, respectively. The initial temperature of the column was set at $50^{\circ} \mathrm{C}$ for 1 minute and then was increased to $200^{\circ} \mathrm{C}$ at the rate of $25^{\circ} \mathrm{C} /$ minute and increased to $230^{\circ} \mathrm{C}$ at the rate of $3^{\circ} \mathrm{C} /$ minute with 18 minutes hold time. $1 \mu$ solution containing FAME was injected. The flow rate of $\mathrm{H}_{2}$ was set at $40 \mathrm{ml} /$ minute with a split ratio of 50:1. FA identification was carried out by comparing the retention times of FAMEs in PSO samples with those in FAME standards consisting of 37 FAMEs (CRM47885 FAME Mix 37 Supelco).

\section{Determination of antioxidant activity}

The antioxidant activities in vitro of PSO samples were assessed using $\mathrm{ABTS}^{++}$assay, DPPH assay, and bleaching assay of $\beta$-carotene.

Determination of antioxidant using DPPH assay

Antiradical activity using DPPH was carried out according to Brand-Williams et al. (1995) and Casoni et al. (2019). PSO samples $(80 \mathrm{mg}$ ) were added to $1.0 \mathrm{ml}$ of DPPH ethanolic solution at a concentration of $0.4 \mathrm{mM}$ and $3.9 \mathrm{ml}$ of ethanol. The absorbance of evaluated samples was measured at $515 \mathrm{~nm}$ after an operational time of 30 minutes in darkness at ambient temperature. The absorbance measurement of evaluated samples was corrected with blank absorbance containing ethanol and the studied PSO sample. The scavenging activity (\%) of the DPPH radical was calculated using

$$
\begin{gathered}
\mathrm{DPPH} \text { radical scavenging } \\
\text { activity }(\%)=
\end{gathered} \frac{\left(\mathrm{Abs}_{\text {control }}-\mathrm{Abs}_{\text {sample }}\right)}{\mathrm{Abs}_{\text {control }}} \times 100
$$

\section{Determination of antioxidant using ABTS assay}

ABTS assay was carried out according to Ortega-Ortega et al.'s (2017) study, with slight modification. ABTS ${ }^{++}$radical cation was produced by reacting ABTS $7 \mathrm{mM}$ with potassium persulfate $2.45 \mathrm{mM}$ in darkness at an ambient temperature for 16 hours. The $\mathrm{ABTS}^{\bullet+}$ solution was diluted with deionized water to get the absorbance value of around $0.7(0.63-0.77)$ at wavelength $753 \mathrm{~nm}$. An aliquot of $40 \mathrm{mg}$ of sample was added 
with $4950 \mu \mathrm{l}$ of diluted $\mathrm{ABTS}^{\bullet+}$, and the absorbance was measured after 7 minutes in darkness at an ambient temperature at 753 $\mathrm{nm}$ (spectrophotometer, model U-2900). The percentage (\%) of radical scavenging of ABTS was calculated as follows:

$$
\begin{gathered}
\text { ABTS radical scavenging } \\
\text { activity }(\%)=
\end{gathered} \frac{\left(\mathrm{Abs}_{\text {control }}-\mathrm{Abs}_{\text {sample }}\right)}{\mathrm{Abs}_{\text {control }}} \times 100 .
$$

\section{$\beta$-Carotene bleaching assay}

The assay of $\beta$-carotene bleaching was carried out as mentioned by Hsouna et al. (2013) and Takada et al. (2006). The mixture of $\beta$-carotene and linoleic acid was made by adding $25 \mathrm{mg}$ of $\beta$-carotene with $10 \mathrm{ml}$ chloroform, $250 \mu \mathrm{l}$ of linoleic acid, and $2.0 \mathrm{~g}$ Tween-20. After that, chloroform was evaporated and added with 1.01 of distilled water (oxygen saturated), and the mixture was shaken vigorously. $4.0 \mathrm{ml}$ of this mixture was dispensed into the test tube and added with $10 \mu \mathrm{l}$ PSO. The emulsion was subjected to incubation for 2 hours at a temperature $50^{\circ} \mathrm{C}$. After that, the absorbance was measured at wavelength $459 \mathrm{~nm}$. The antioxidant based on bleaching of $\beta$-carotene was computed as follows:

$$
\text { antioxidant activity }=\frac{\left(\operatorname{degr}_{\text {control }}-\text { degr }_{\text {sample }}\right)}{\operatorname{degr}_{\text {control }}} \times 100
$$

in which degradation rate was calculated as follows:

degradation rate $(\operatorname{degr})=\left(\mathrm{Lu}\left[A_{0} / A_{\mathrm{t}}\right]\right)$,

where $A_{0}$ is the absorbance value of the PSO sample at zero times and $A_{\mathrm{t}}$ is the absorbance of the sample after 2 hours of incubation.

\section{Determination of total phenolic content}

The total phenolic content of PSO was determined by using Folin-Ciocalteu's reagent methods as mentioned in DelfanHosseini et al.'s (2017) study with slight modification. 0.4 g PSO was dissolved in $1 \mathrm{ml} n$-hexane and the extraction procedure was carried out using $1 \mathrm{ml}$ methanol:water (80\%:20\% v/v). $200 \mu \mathrm{l}$ of methanol:water phase was mixed with $0.4 \mathrm{ml}$ of Folin-Ciocalteu's reagent and $4.0 \mathrm{ml} \mathrm{Na}_{2} \mathrm{CO}_{3}$ solution in a $10 \mathrm{ml}$ volumetric flash and then was adjusted to volume with Aquadest. The measurement of absorbance was made at $750 \mathrm{~nm}$ after 60 minutes. The reference standard of gallic acid at $0.0625-4 \mu \mathrm{g} / \mathrm{ml}$ in methanol was applied for preparing the calibration curve.

\section{RESULTS AND DISCUSSION}

\section{The moisture contents and extraction yield}

Moisture analysis of pumpkin seed showed that the contents of water and volatile matter were in the range of $6.72 \%$ $8.88 \%$ (Table 1). The low moisture of the samples before being subjected to microwave treatment can make them more brittle. As a consequence, the yield of PSO during extraction can be increased (Uquiche et al., 2008). The yield of PSO extraction from different origins and extraction methods was expressed as the $\%$ of PSO obtained, as compiled in Table 2 . The highest yield was obtained using the Soxhlet method compared to that obtained using the UAE and hot pressing methods. The high yield of PSO obtained by the Soxhlet method could be attributed to extended contact and repeated washing to eight cycles at high temperature (Ortega-Ortega et al., 2017). The obtained results were in line with those reported for black seed oil (Khoddami et al., 2011), grape seed oil (Da Porto et al., 2013), and purslane seed oil (DelfanHosseini et al., 2017).

\section{Physicochemical properties of PSO}

Table 3 shows the physicochemical properties of PSO from different origins extracted using different methods. The acid value $(\mathrm{AV})$ and peroxide value (PV) were used as the most important characteristics for seed oil. Meanwhile, the saponification value (SV) and iodine value (IV) were used as quality parameters for seed oil. The AV represents the amount of free FAs in the oil. AVs of the PSO were within the range of 4.37-8.63 mg Potassium Hydroxide $(\mathrm{KOH}) / \mathrm{g}$ oil. The similar results in AVs of PSO were reported by Rezig et al. (2012) in which the AV value obtained was $7.54 \mathrm{mg} \mathrm{KOH} / \mathrm{g}$ oil and by Jiao et al. (2014) (6.97-7.08 $\mathrm{mg} \mathrm{KOH} / \mathrm{g}$ oil), but the reported AVs of PSO in this study were higher than that reported by Habib et al. (2015) (0.516 mg KOH/g oil). The difference was attributed to the sources of PSO used, namely unrefined oil (this study) and refined oil (Habib et al., 2015). Based on the ANOVA and Tukey's test, the hot press extracted oil had the lowest AVs but there is no significant difference between ultrasound-assisted extracted oil and that of Soxhlet $(p>0.05)$ and there are no significant effects on the different origins of PSO $(p>0.05)$.

The PV indicated the degree of oxidation of the oil. The low value of PV indicated the high resistance to oxidation (Haile et al., 2019). PVs of PSO from different origins and different extraction methods were found to be in the range of $3.15-5.61 \mathrm{meq} / \mathrm{kg}$. PVs of PSO showed a significant difference between extraction methods $(p<0.05)$. The highest PVs were found in PSOs extracted by the Soxhlet method which is attributed to the high temperature used during the extraction. The SV is an indicator of chain length and molecular weight of FAs composed of fats and oils. SVs of the PSO from different origins and extraction methods ranged from 145.28 to 195.27 $\mathrm{mg} \mathrm{KOH} / \mathrm{g}$ oil. SVs of PSO were also reported by Rezig et al.

Table 1. Moisture content of PSO obtained from different origins.

\begin{tabular}{ccc}
\hline No. & Origin & Moisture content (\%) \\
\hline 1 & Blora & $6.72 \pm 0.33$ \\
2 & Cepu & $7.47 \pm 0.39$ \\
3 & Gondomanan & $7.02 \pm 0.25$ \\
4 & Gunung Kidul & $8.88 \pm 0.43$ \\
5 & Kopeng & $7.11 \pm 0.03$ \\
6 & Muntilan & $7.96 \pm 0.74$ \\
7 & Palagan & $8.66 \pm 0.82$ \\
8 & Parakan & $7.27 \pm 0.31$ \\
9 & Pati & $6.93 \pm 0.33$ \\
10 & Weleri & $7.52 \pm 0.48$ \\
\hline
\end{tabular}


Table 2. Yield (\%) of PSO obtained from different origins and extraction methods.

\begin{tabular}{lcccc}
\hline No. & Origin & Hot pressing & UAEld (\%) & Soxhlet \\
\hline & & 27.08 & 25.16 & 38.24 \\
2 & Blora & 27.06 & 26.77 & 37.59 \\
3 & Cepu & 25.58 & 27.56 & 35.34 \\
4 & Gondomanan & 25.52 & 28.85 & 41.74 \\
5 & Gunung Kidul & 20.21 & 26.66 & 37.09 \\
6 & Kopeng & 22.89 & 26.87 & 40.62 \\
7 & Muntilan & 24.39 & 29.86 & 41.35 \\
8 & Palagan & 20.63 & 26.97 & 38.91 \\
9 & Parakan & 23.31 & 27.22 & 40.57 \\
10 & Pati & 24.54 & 35.34 & 45.05 \\
& Weleri & 24.12 & 28.13 & 39.65 \\
\hline
\end{tabular}

UAE: ultrasound-assisted extraction.

Table 3. Physicochemical properties of PSO from different regions and extraction methods.

\begin{tabular}{cccccc}
\hline Origin & Extraction method & SV $(\mathbf{m g ~ K O H} / \mathbf{g}$ oil $)$ & $\mathbf{A V}(\mathbf{m g ~ K O H} / \mathbf{g ~ o i l})$ & $\mathbf{P V}(\mathbf{m e q} / \mathbf{k g})$ & $\mathbf{I V}(\mathbf{g ~ I} / \mathbf{1 0 0} \mathbf{g ~ o i l})$ \\
\hline Palagan & Hot pressing & $192.32 \pm 2.950^{\mathrm{a}}$ & $4.37 \pm 0.283^{\mathrm{b}}$ & $3.19 \pm 0.028^{\mathrm{d}}$ & $96.76 \pm 1.920^{\mathrm{b}}$ \\
& Soxhlet & $181.26 \pm 0.247^{\mathrm{bc}}$ & $8.50 \pm 0.028^{\mathrm{a}}$ & $5.58 \pm 0.028^{\mathrm{a}}$ & $84.89 \pm 2.550^{\mathrm{d}}$ \\
& UAE & $155.34 \pm 1.530^{\mathrm{d}}$ & $8.47 \pm 0.028^{\mathrm{a}}$ & $3.99 \pm 0.021^{\mathrm{c}}$ & $91.75 \pm 0.247^{\mathrm{c}}$ \\
\multirow{2}{*}{ Weleri } & Hot pressing & $195.27 \pm 2.910^{\mathrm{a}}$ & $4.65 \pm 0.021^{\mathrm{b}}$ & $3.65 \pm 0.255^{\mathrm{c}}$ & $98.16 \pm 0.438^{\mathrm{b}}$ \\
& Soxhlet & $183.64 \pm 0.184^{\mathrm{b}}$ & $8.61 \pm 0.049^{\mathrm{a}}$ & $5.35 \pm 0.212^{\mathrm{a}}$ & $85.49 \pm 0.198^{\mathrm{d}}$ \\
& UAE & $157.04 \pm 1.322^{\mathrm{d}}$ & $8.48 \pm 0.056^{\mathrm{a}}$ & $4.81 \pm 0.063^{\mathrm{b}}$ & $94.26 \pm 0.120^{\mathrm{bc}}$ \\
& Kopeng & $173.56 \pm 3.360^{\mathrm{c}}$ & $4.55 \pm 0.417^{\mathrm{b}}$ & $3.15 \pm 0.014^{\mathrm{d}}$ & $113.61 \pm 1.780^{\mathrm{a}}$ \\
& Hot pressing & $156.56 \pm 0.021^{\mathrm{d}}$ & $8.63 \pm 0.332^{\mathrm{a}}$ & $5.61 \pm 0.042^{\mathrm{a}}$ & $81.47 \pm 0.481^{\mathrm{d}}$ \\
& Soxhlet & $145.28 \pm 3.010^{\mathrm{e}}$ & $8.29 \pm 0.070^{\mathrm{a}}$ & $4.02 \pm 0.035^{\mathrm{c}}$ & $91.255 \pm 0.615^{\mathrm{c}}$ \\
\hline
\end{tabular}

UAE: ultrasound-assisted extraction.

Means with different lowercase letters within a column in each origin and extraction method are significantly different $(p<0.05)$.

Values are mean $\pm \mathrm{SD}$ of duplicate.

(2012) to be $175 \mathrm{mg} \mathrm{KOH} / \mathrm{g}$ oil, Jiao et al. (2014) to be 183.37 $184.41 \mathrm{mg} \mathrm{KOH} / \mathrm{g}$ oil, and Habib et al. (2015) to be 193.73 $\mathrm{mg} \mathrm{KOH} / \mathrm{g}$ oil. The difference of SVs in this study and those reported by other researches may be attributable to different origins, cultivation age of pumpkin, and environmental conditions. SVs of PSOs showed a significant difference between extraction methods $(p<0.05)$. The IVs indicated the unsaturated bond present in fats and oils. The higher the IV, the greater the number of $\mathrm{C}=\mathrm{C}$ double bonds (Aremu et al., 2006; Lixia et al., 2018). IVs of PSO from different extractions and different origins in this study were in the range of 81.47-113.61 $\mathrm{g} \mathrm{I}_{2} / \mathrm{g}$ oil. The IV of PSO extracted using hot pressing is higher than those of other oils $(p<0.05)$. These results were similar to those reported by Habib et al. (2015) (114.33 $\mathrm{g} \mathrm{I}_{2} / \mathrm{g}$ oil), Badr et al. (2011) (109 $\mathrm{g} \mathrm{I}_{2} / \mathrm{g}$ oil), and El-Adawy and Taha (2001) (109 $\mathrm{g} \mathrm{I}_{2} / \mathrm{g}$ oil).

\section{FA composition of PSO}

The FA composition of PSOs from different origins extracted using the different methods is shown in Table 4. Four FAs were identified as dominant FAs in PSO, including palmitate, stearate, oleic, and linoleate (Fig. 1b). These findings are in agreement with those reported by Kulaitienè et al. (2018) and Rezig et al. (2018). These results obtained also indicated that the different extraction methods have no effect on the FA composition of PSO $(p>0.05)$.

\section{Antioxidant activity of PSO}

The antioxidant activities of PSOs as evaluated by the DPPH radical scavenging assay, ABTS assay, and $\beta$-carotene bleaching are shown in Table 5. The highest antioxidant activity was found in PSO from Gunung Kidul extracted by hot pressing on both DPPH radical assay (98.71\%) and ABTS assay (88.08\%) with total phenolic content of $142.61 \mu \mathrm{g}$ gallic acid equivalent/g 


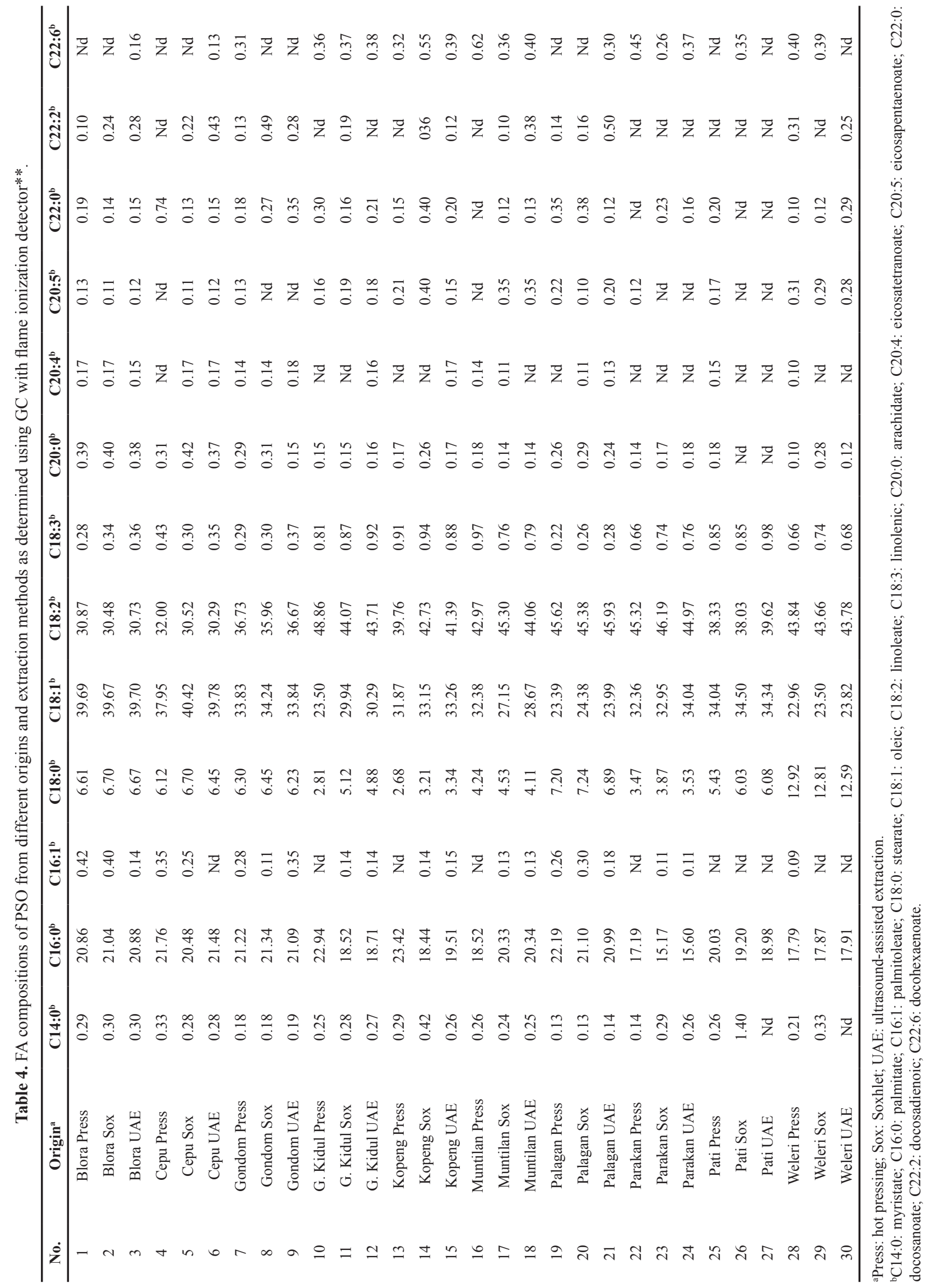




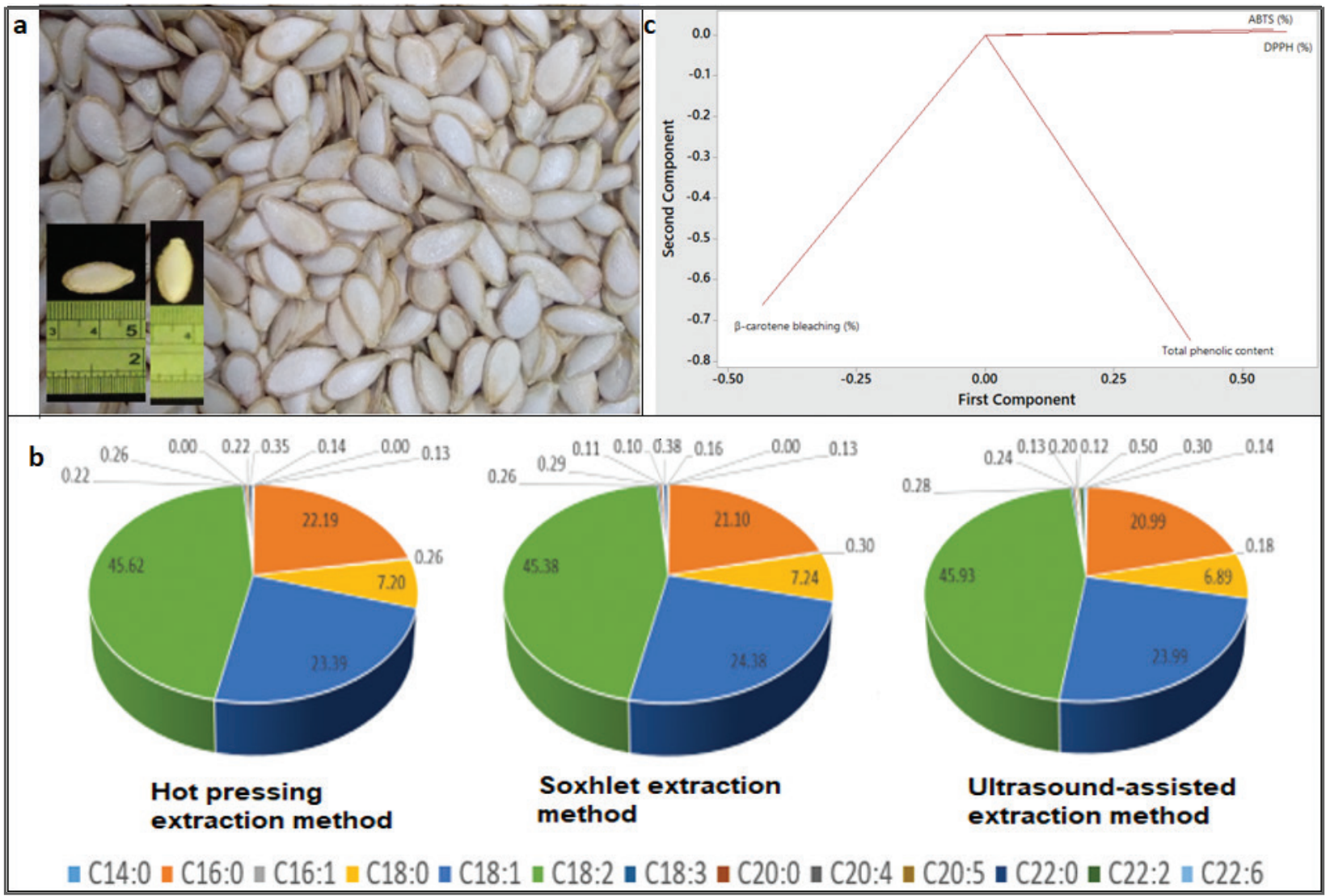

Figure 1. (a) Example of pumpkin seeds (C. moschata Duchesne) used in this study. (b) FA composition of PSO from Palagan region, Yogyakarta. (c) Loading plot of principal component analysis for evaluating the correlation between antioxidant activities and phenolic compounds.

Table 5. Antioxidant activity of PSO from different origins and extraction methods.

\begin{tabular}{|c|c|c|c|c|c|}
\hline No. & Origin & DPPH (\%) & ABTS (\%) & $\begin{array}{c}\beta \text {-Carotene bleaching } \\
(\%)\end{array}$ & $\begin{array}{l}\text { Total phenolic content } \\
\qquad\left(\mu \mathrm{g} \mathrm{g}^{-1} \text { oil }\right)\end{array}$ \\
\hline 1 & Blora Press & $44.20 \pm 0.07^{\circ}$ & $45.41 \pm 0.16^{\circ}$ & $51.35 \pm 11.14^{\text {abcdef }}$ & $110.99 \pm 1.44^{b}$ \\
\hline 2 & Blora Sox & $23.93 \pm 0.22^{v}$ & $32.14 \pm 0.18^{\mathrm{w}}$ & $60.02 \pm 12.59^{\mathrm{abcd}}$ & $60.24 \pm 2.50^{\mathrm{hi}}$ \\
\hline 3 & Blora UAE & $24.02 \pm 0.20^{v}$ & $37.48 \pm 0.00^{v}$ & $64.19 \pm 12.34^{\mathrm{abc}}$ & $41.93 \pm 1.44^{\mathrm{jklm}}$ \\
\hline 4 & Cepu Press & $50.67 \pm 0.75^{\mathrm{k}}$ & $55.31 \pm 0.32^{\mathrm{hi}}$ & $38.28 \pm 8.03^{\text {abcdefg }}$ & $71.05 \pm 5.20^{\mathrm{fg}}$ \\
\hline 5 & Cepu Sox & $32.26 \pm 0.78^{\mathrm{rs}}$ & $37.48 \pm 0.41^{\mathrm{v}}$ & $53.33 \pm 0.51^{\mathrm{abcde}}$ & $31.12 \pm 1.44^{\mathrm{no}}$ \\
\hline 6 & Cepu UAE & $30.01 \pm 0.13^{t}$ & $38.15 \pm 0.09^{\mathrm{uv}}$ & $52.79 \pm 3.47^{\text {abcde }}$ & $51.92 \pm 2.50^{\mathrm{hij}}$ \\
\hline 7 & Gondomanan Press & $48.04 \pm 0.82^{\mathrm{lm}}$ & $51.84 \pm 0.09^{j}$ & $25.98 \pm 2.62^{\mathrm{defg}}$ & $26.96 \pm 0.00^{\mathrm{op}}$ \\
\hline 8 & Gondomanan Sox & $28.37 \pm 0.27^{\mathrm{u}}$ & $47.85 \pm 0.45^{1}$ & $38.29 \pm 6.88^{\text {abcdefg }}$ & $61.07 \pm 1.44^{\mathrm{gh}}$ \\
\hline 9 & Gondomanan UAE & $36.27 \pm 0.82^{q}$ & $49.87 \pm 0.39^{k}$ & $36.82 \pm 2.02^{\text {bcdefg }}$ & $27.79 \pm 3.81^{\mathrm{op}}$ \\
\hline 10 & Gunung Kidul Press & $98.71 \pm 0.00^{\mathrm{a}}$ & $88.08 \pm 0.18^{\mathrm{a}}$ & $15.48 \pm 11.37^{g}$ & $142.61 \pm 1.44^{\mathrm{a}}$ \\
\hline 11 & Gunung Kidul Sox & $57.44 \pm 0.22^{i}$ & $60.34 \pm 0.00^{\mathrm{e}}$ & $46.51 \pm 2.96^{\text {abcdefg }}$ & $51.08 \pm 1.44^{\mathrm{hij}}$ \\
\hline 12 & Gunung Kidul UAE & $59.29 \pm 0.37^{\mathrm{gh}}$ & $55.37 \pm 0.27^{\mathrm{hi}}$ & $68.68 \pm 2.40^{\mathrm{ab}}$ & $135.95 \pm 3.81^{\mathrm{a}}$ \\
\hline 13 & Kopeng Press & $58.95 \pm 0.07^{\mathrm{h}}$ & $54.54 \pm 0.32^{\mathrm{i}}$ & $48.10 \pm 15.44^{\text {abcdefg }}$ & $51.92 \pm 0.00^{\mathrm{hij}}$ \\
\hline 14 & Kopeng Sox & $30.83 \pm 0.82^{\mathrm{st}}$ & $38.83 \pm 1.17^{\text {tu }}$ & $69.30 \pm 12.75^{\mathrm{ab}}$ & $35.28 \pm 5.20^{\operatorname{lmno}}$ \\
\hline 15 & Kopeng UAE & $33.33 \pm 0.54^{\mathrm{r}}$ & $42.20 \pm 0.09^{q}$ & $73.01 \pm 7.75^{\mathrm{a}}$ & $50.25 \pm 3.81^{\mathrm{ij}}$ \\
\hline 16 & Muntilan Press & $64.77 \pm 0.20^{\mathrm{e}}$ & $68.43 \pm 0.31^{\mathrm{b}}$ & $16.91 \pm 1.83^{\mathrm{fg}}$ & $98.51 \pm 1.44^{\mathrm{c}}$ \\
\hline
\end{tabular}




\begin{tabular}{|c|c|c|c|c|c|}
\hline No. & Origin & DPPH (\%) & ABTS (\%) & $\begin{array}{c}\beta \text {-Carotene bleaching } \\
(\%)\end{array}$ & $\begin{array}{c}\text { Total phenolic content } \\
\left(\mu \mathrm{g} \mathrm{g}^{-1} \text { oil }\right)\end{array}$ \\
\hline 17 & Muntilan Sox & $61.66 \pm 0.07^{f}$ & $65.37 \pm 0.48^{c}$ & $41.57 \pm 6.17^{\text {abcdefg }}$ & $46.09 \pm 1.44^{\mathrm{jk}}$ \\
\hline 18 & Muntilan UAE & $63.99 \pm 0.07^{\mathrm{e}}$ & $69.36 \pm 0.16^{\mathrm{b}}$ & $59.69 \pm 6.06^{\mathrm{abcd}}$ & $81.87 \pm 7.49^{\mathrm{de}}$ \\
\hline 19 & Palagan Press & $61.23 \pm 0.33^{f}$ & $40.95 \pm 0.09^{\mathrm{rs}}$ & $29.45 \pm 8.93^{\text {cdefg }}$ & $45.26 \pm 5.20^{\mathrm{jkl}}$ \\
\hline 20 & Palagan Sox & $31.18 \pm 0.22^{\mathrm{st}}$ & $55.42 \pm 0.39^{h i}$ & $54.06 \pm 8.59^{\text {abcde }}$ & $39.44 \pm 2.50^{\mathrm{klmn}}$ \\
\hline 21 & Palagan UAE & $40.32 \pm 0.97^{p}$ & $57.13 \pm 1.09^{\mathrm{g}}$ & $68.79 \pm 15.74^{\mathrm{ab}}$ & $46.15 \pm 9.99^{\mathrm{jk}}$ \\
\hline 22 & Parakan Press & $54.51 \pm 0.27^{j}$ & $46.35 \pm 0.00^{\text {no }}$ & $31.85 \pm 4.95^{\mathrm{cdefg}}$ & $59.40 \pm 0.00^{\mathrm{hi}}$ \\
\hline 23 & Parakan Sox & $46.31 \pm 0.00^{\mathrm{n}}$ & $43.86 \pm 0.31^{\mathrm{p}}$ & $68.32 \pm 4.08^{\mathrm{ab}}$ & $76.88 \pm 0.00^{\mathrm{ef}}$ \\
\hline 24 & Parakan UAE & $46.83 \pm 0.00^{\mathrm{mn}}$ & $46.66 \pm 0.00^{1 \mathrm{lmn}}$ & $42.28 \pm 10.08^{\text {abcdefg }}$ & $51.08 \pm 2.88^{\text {hij }}$ \\
\hline 25 & Pati Press & $60.67 \pm 0.00^{\mathrm{fg}}$ & $58.48 \pm 0.16^{\mathrm{f}}$ & $26.62 \pm 14.41^{\mathrm{defg}}$ & $33.61 \pm 1.44^{\mathrm{mno}}$ \\
\hline 26 & Pati Sox & $28.16 \pm 0.07^{u}$ & $38.10 \pm 0.41^{\mathrm{uv}}$ & $73.28 \pm 1.26^{\mathrm{a}}$ & $27.79 \pm 1.44^{\mathrm{op}}$ \\
\hline 27 & Pati UAE & $39.67 \pm 0.58^{p}$ & $42.20 \pm 0.24^{\mathrm{q}}$ & $56.51 \pm 6.94^{\text {abcde }}$ & $35.28 \pm 2.88^{\mathrm{lmno}}$ \\
\hline 28 & Weleri Press & $67.62 \pm 0.20^{\mathrm{d}}$ & $62.31 \pm 0.50^{\mathrm{d}}$ & $41.63 \pm 12.63^{\text {abcdefg }}$ & $87.69 \pm 3.81^{\mathrm{d}}$ \\
\hline 29 & Weleri Sox & $37.56 \pm 0.52^{q}$ & $41.21 \pm 0.00^{\mathrm{qr}}$ & $63.19 \pm 1.08^{\mathrm{abc}}$ & $103.50 \pm 1.44^{\mathrm{bc}}$ \\
\hline 30 & Weleri UAE & $40.62 \pm 0.81^{\mathrm{p}}$ & $46.60 \pm 0.09^{\mathrm{mno}}$ & $56.50 \pm 4.83^{\text {abcde }}$ & $36.11 \pm 3.81^{\mathrm{klmno}}$ \\
\hline
\end{tabular}

Press: hot pressing; Sox: Soxhlet; UAE: ultrasound-assisted extraction.

Means with different lowercase letters within a column in each origin and extraction method are significantly different $(p<0.05)$.

Values are mean $\pm \mathrm{SD}$ of triplicate.

oil. Meanwhile, the highest $\beta$-carotene bleaching was found in PSO from Pati, Central Java, extracted by the Soxhlet method. Figure 1c shows the relationship between antioxidant activities and total phenolic content of PSO as evaluated using the loading plot of principal component analysis.

\section{CONCLUSION}

Comparing the three extraction methods, the PSO extracted by the hot pressing extraction method presented a lower yield but good physicochemical properties and higher antioxidant activities as evaluated by the DPPH radical scavenging assay, ABTS assay, and $\beta$-carotene bleaching assay. PSO collected from different origins showed different physicochemical properties. PSOs have the potential to be used in food industries especially for functional food oil applications.

\section{ACKNOWLEDGMENTS}

The authors acknowledge Universitas Gadjah Mada (UGM) for financial support through scheme of Program PostDoctoral Tahun 2021 with contract number: 6162/UN1/DITLIT/ DIT-LIT/PT/2021 Awarded to Prof. Dr. Abdul Rohman.

\section{AUTHORS' CONTRIBUTIONS}

Irnawati carried out the research activities, data acquisition, data interpretation, statistical analysis, and prepared the manuscript. Anjar Windarsih prepared the manuscript. Sugeng Riyanto, Sudibyo Martono, and Abdul Rohman conceptualized and designed the research and critically analyzed the manuscript. All authors read and agreed on the published version of the manuscript.

\section{CONFLICTS OF INTEREST}

The authors report no financial or any other conflicts of interest in this work.

\section{ETHICAL APPROVALS}

This study does not involve experiments on animals or human subjects.

\section{PUBLISHER'S NOTE}

This journal remains neutral with regard to jurisdictional claims in published institutional affiliation.

\section{REFERENCES}

AOAC. The official methods of analysis. 17th edition, AOAC, Rockville, MD, 2000.

Aremu MO, Olaofe O, Akintayo ET. Chemical composition and physicochemical characteristics of two varieties of bambara groundnut (Vigna subterrenea) flours. J Appl Sci, 2006; 6:1900-3.

Badr SEA, Shaaban M, Elkholy YM, Helal MH, Hamza AS, Masoud MS, Safty MMEl. Natural product research : formerly natural product letters chemical composition and biological activity of ripe pumpkin fruits (Cucurbita pepo L.) cultivated in Egyptian habitats. Nat Prod Res, 2011; 16:37-41.

Bharti SK, Kumar A, Sharma NK, Prakash O, Jaiswal SK, Krishnan S, Gupta AK, Kumar A. Tocopherol from seeds of Cucurbita pepo against diabetes: validation by in vivo experiments supported by computational docking. J Formos Med Assoc, 2013; 112:676-90.

Brand-Williams W, Cuvelier ME, Berset C. Standard calibration techniques. Lebensm Wiss Technol, 1995; 28:25-30.

Cândido FG, de Oliveira FCE, Lima MFC, Pinto CA, da Silva LL, Martino HSD, Santos MH dos, Alfenas RdeCG. Addition of pooled pumpkin seed to mixed meals reduced postprandial glycemia: a randomized placebo-controlled clinical trial. Nutr Res, 2018; 56:90-7.

Casoni D, Simion IM, Sârbu C. A comprehensive classification of edible oils according to their radical scavenging spectral profile evaluated by advanced chemometrics. Spectrochim Acta A Mol Biomol Spectros, 2019; 213:204-9.

Dang TQ, Bui HQH. Effect of roasting and microwave heating on the yield, quality, total phenolics and antioxidant capacity of oil from red pumpkin seed. Ec Nutrition, 2019; 8:588-96.

Da Porto C, Porretto E, Decorti D. Comparison of ultrasoundassisted extraction with conventional extraction methods of oil and 
polyphenols from grape (Vitis vinifera L.) seeds. Ultrason Sonochem, 2013; 20:1076-80.

Delfan-Hosseini S, Nayebzadeh K, Mirmoghtadaie L, Kavosi M, Hosseini SM. Effect of extraction process on composition, oxidative stability and rheological properties of purslane seed oil. Food Chem, 2017; 222:61-6.

El-Adawy TA, Taha KM. Characteristics and composition of watermelon, pumpkin, and paprica seed oils and flours. J Agric Food Chem, 2001; 49:1253-9.

Elfiky SA, Elelaimy IA, Hassan AM, Ibrahim HM, Elsayad RI. Protective effect of pumpkin seed oil against genotoxicity induced by azathioprine. JOBAZ, 2012; 65:289-98.

Habib A, Biswas S, Siddique AH, Manirujjaman M, Uddin B, Hasan, S., Khan MMH, Uddin M, Islam M, Hasan M, Rahman M, Asaduzzaman M, Sohanur RM, Khatun M, Islam MA, Rahman, M. Nutritional and lipid composition analysis of pumpkin seed (Cucurbita maxima Linn.). Nut Food Sci, 2015; 05:1-5.

Haile M, Duguma HT, Chameno G, Kuyu CG. Effects of location and extraction solvent on physico chemical properties of Moringa stenopetala seed oil. Heliyon, 2019; 5:1-5.

Hsouna AB, Hamdi N, Halima NB, Abdelkafi S. Characterization of essential oil from Citrus aurantium L. flowers: antimicrobial and antioxidant activities. J Oleo Sci, 2013; 62:763-72.

Irnawati, Riyanto S, Martono S, Rohman A. The optimization of ultrasonic method for the extraction of pumpkin seed (Cucurbita maxima). Indonesian J Chemom Pharm Anal, 2020; 1:23-32.

Irnawati, Riyanto S, Martono S, Rohman A. The employment of FTIR spectroscopy and chemometrics for the classification and prediction of antioxidant activities of pumpkin seed oils from different origins. J Appl Pharm Sci, 2021; 11(05):100-7.

Jiao J, Li ZG, Gai QY, Li XJ, Wei FY, Fu YJ, Ma W. Microwaveassisted aqueous enzymatic extraction of oil from pumpkin seeds and evaluation of its physicochemical properties, fatty acid compositions and antioxidant activities. Food Chem, 2014; 147:17-24.

Khoddami A, Ghazali HM, Yassoralipour A, Ramakrishnan Y, Ganjloo A. Physicochemical characteristics of Nigella seed (Nigella sativa L.) oil as affected by different extraction methods. J Am Oil Chem Soc, 2011; 88:533-40.

Kim MY, Kim EJ, Kim YN, Choi C, Lee BH. Comparison of the chemical compositions and nutritive values of various pumpkin (Cucurbitaceae) species and parts. Nutr Res Pract, 2012;6:21-7.

Koubaa M, Mhemdi H, Barba FJ, Angelotti A, Bouaziz F, Chaabouni SE, Vorobiev E. Seed oil extraction from red prickly pear using hexane and supercritical $\mathrm{CO} 2$ : assessment of phenolic compound composition, antioxidant and antibacterial activities. J Sci Food Agric, 2017; 97:613-20.

Kulaitienė J, Černiauskienė J, Jarienė E, Danilčenko $\mathrm{H}$, Levickienè D. Antioxidant activity and other quality parameters of cold pressing pumpkin seed oil. Not Bot Hort Agrobot Cluj, 2018; 46:161-6.

Lixia H, Cuicui L, Jihong Q. Comparison of the physicochemical characteristics of Pinus koraiensis L. nut oils from different extraction technologies. GOST, 2018; 1:113-8.

Medjakovic S, Hobiger S, Ardjomand-Woelkart K, Bucar F, Jungbauer A. Pumpkin seed extract: cell growth inhibition of hyperplastic and cancer cells, independent of steroid hormone receptors. Fitoterapia, 2016; 110:150-6.

Montesano D, Blasi F, Simonetti MS, Santini A, Cossignani L. Chemical and nutritional characterization of seed oil from Cucurbita maxima L. (Var. Berrettina) pumpkin. Foods, 2018; 7:30.
Murkovic M, Piironen V, Lampi AM, Kraushofer T. Changes in chemical composition of pumpkin seeds during the roasting process for production of pumpkin seed oil (Part 1: non-volatile compounds). Food Chem, 2004; 84:359-65.

Nakić SN, Rade D, Škevin D, Štrucelj D, Mokrovčak Ž, Bartolić M. Chemical characteristics of oils from naked and husk seeds of Cucurbita pepo L. Eur J Lipid Sci Technol, 2006; 108:936-43.

Nishimura M, Ohkawara T, Sato H, Takeda H, Nishihira J. Pumpkin seed oil extracted from Cucurbita maxima improves urinary disorder in human overactive bladder. J Tradit Complement Med, 2014; $4: 72-4$.

Ortega-Ortega M de los A, Cruz-Cansino N del S, Alanís-García E, Delgado-Olivares L, Ariza-Ortega JA, Amírezmoreno ER, ManríquezTorres JD. Optimization of ultrasound extraction of cactus pear (Opuntia ficus indica) seed oil based on antioxidant activity and evaluation of its antimicrobial activity. J Food Qual, 2017; 2017:1-10.

Perez Gutierrez RM. Review of Cucurbita pepo (pumpkin) its phytochemistry and pharmacology. Med Chem, 2016; 6:12-21.

Rezig L, Chouaibi M, Msaada K, Hamdi S. Chemical composition and profile characterisation of pumpkin (Cucurbita maxima) seed oil. Ind Crops Prod, 2012; 37:82-7.

Rezig L, Chouaibi M, Ojeda-Amador RM, Gomez-Alonso S, Salvador MD, Fregapane G, Hamdi S. Cucurbita maxima pumpkin seed oil: from the chemical properties to the different extracting techniques. Not Bot Horti Agrobot Cluj, 2018; 46:663-9.

Rohman A, Irnawati. Pumpkin (Cucurbita maxima) seed oil chemical composition, antioxidant activities and its authentication analysis. Food Res, 2020; 4:578-84.

Salgin U, Korkmaz H. A green separation process for recovery of healthy oil from pumpkin seed. J Supercrit Fluids, 2011; 58:239-48.

Stevenson DG, Eller FJ, Wang L, Jane JL, Wang T, Inglett G.E. Oil and tocopherol content and composition of pumpkin seed oil in 12 cultivars. J Agric Food Chem, 2007; 55:4005-13.

Takada H, Kokubo K, Matsubayashi K, Oshima T. Antioxidant activity of supramolecular water-soluble fullerenes evaluated by $\beta$-carotene bleaching assay. Biosci Biotechnol Biochem, 2006; 70:3088-93.

The Ministry of Health. (1979). Farmakope Indonesia. 3rd edition, Direktorat Jenderal Pengawasan Obat dan Makanan Departemen Kesehatan R.I, Jakarta, Indonesia.

Uquiche E, Jeréz M, Ortíz J. Effect of pretreatment with microwaves on mechanical extraction yield and quality of vegetable oil from Chilean hazelnuts (Gevuina avellana Mol). Innov Food Sci Emerg Technol, 2008; 9:495-500.

How to cite this article:

Irnawati I, Riyanto S, Martono S, Windarsih A, Rohman A. Physicochemical properties and antioxidant activities of pumpkin seed oil as affected by different origins and extraction methods. J Appl Pharm Sci, 2022; 12(03):115-122. 